\title{
Food hubs play an essential role in the COVID-19 response in Hawai' $i$
}

\author{
Saleh Azizi Fardkhales a* \\ Kahumana Organic Farms
}

SPECIAL ISSUE COSPONSORED BY INFAS: THE IMPACT OF COVID-19 ON FOOD SYSTEMS

Noa Kekuewa Lincoln ${ }^{b}$

College of Tropical Agriculture, University of Hawaíi at Mānoa

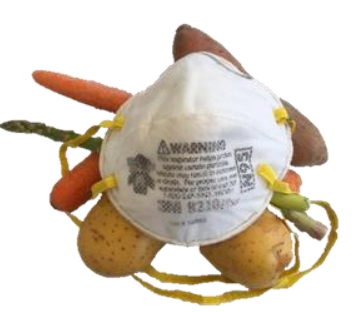

Inter-institutional

Network for

Food and

Agricultural

Sustainability

Submitted October 4, 2020 / Revised December 3, 2020, and January 4, 2021 /

Accepted January 6, 2021 / Published online March 15, 2021

Citation: Azizi Fardkhales, S., \& Lincoln, N. K. (2021). Food hubs play an essential role

in the COVID-19 response in Hawai'i. Journal of Agriculture, Food Systems, and Community

Development, 10(20), 53-70. https://doi.org/10.5304/jafscd.2021.102.036

Copyright (C) 2021 by the Authors. Published by the Lyson Center for Civic Agriculture and Food Systems. Open access under CC-BY license.

\begin{abstract}
Community food security and food systems resilience have received much emphasis in the last two decades, at least partially in response to mounting challenges and pressures on the global food system. While empirical research shows strong evidence that direct-to-consumer relationships in the food system predominantly serve affluent communities, during the COVID-19 pandemic local food providers have become a necessity through their provision of essential services, such as hunger relief and home deliveries for vulnerable populations. In this paper, we examine the challenges and opportunities of food hubs-

a * Corresponding author: Saleh Azizi Fardkhales, Ph.D., Community Economic Development Coordinator, Kahumana Organic Farms, Wai'anae, HI 96792 USA; azizi@hawaii.edu

b Noa Kekuewa Lincoln, Ph.D., Department of Tropical Plant and Soil Sciences, University of Hawai'i at Mānoa, Honolulu, HI 96822 USA; nlincoln@hawaii.edu

innovations in local food systems that help connect small farmers with local markets-during the COVID-19 pandemic using quantitative and qualitative data from practitioners on the ground. The hubs were not necessarily equipped or experienced in the response needed, but they quickly adapted to the situation and demonstrated success during the pandemic, as illustrated by 200 $300 \%$ growth in performance metrics such as revenues generated, employees retained, customers served, and farmers supported. The performance of the hubs in response to the multiple challenges accompanying the pandemic demonstrates their key role in food system resilience through features of diversity, functional redundancy, and connectivity, suggesting that disaster preparation should consider local food hubs a necessary service. We provide policy suggestions for supporting their role in local food system resilience beyond the pandemic.
\end{abstract}




\section{Keywords}

Food Hubs, Community Food Systems, Resilience, COVID-19, Pandemic, Hawaici, Hawaii, Food System, Participatory Action Research

\section{Introduction}

The concepts of community food security and food systems resilience have received much emphasis in the last two decades, at least partially in response to mounting challenges and pressures on the global food system (Foley et al., 2011; Godfray et al., 2010; Rockström et al., 2017). The intrinsic uncertainties and complexities of food systemssocioecological systems that include, at minimum, food production, processing and packaging, distribution and retail, and consumption (Ericksen, 2008) - mean that they must be able to operate effectively even in the face of multiple, unpredictable drivers of change.

While calls for resilience in food systems have been growing, resilience remains a paradigm rather than a firmly defined concept (Tendall et al., 2015). At the broadest level, resilience can be defined as the capacity to continue to function despite disturbances and shocks. With its roots in ecology, resilience is a system-based approach that acknowledges complex interactions between various components, scales, and links to other sectors (Tendall et al., 2015). Resilience theory suggests that a whole system approach is essential to capturing any resilience effort (Jones, 2013), and that multiple outcomes may be recognized directly, indirectly, and across time scales (Béné, 2020). Although the concept of resilience remains abstract, there are core aspects that are well agreed upon from the fields of ecology, such as diversity, functional redundancy, and connectivity of the players within a system (Ungar, 2018). While a growing body of literature is available on the concept of food system resilience (e.g., Ericksen, 2008; Pingali, Alinovi, \& Sutton, 2005; Tendall et al., 2015), the COVID-19 situation provides an opportunity to observe first-hand the responses and emerging roles of food-system components to a major disruption.

We argue that local food systems are a critical infrastructure for disaster response and in planning for local resiliency. Over the last twenty years, planners have reclaimed involvement in local food systems and aimed to strengthen supports (Pothukuchi \& Kaufman, 1999). Before local food systems became a part of the planning agenda, planners had worked with conservation programs to preserve farmland for agricultural use, but a planning presence in food systems work had been lacking for over a half a century in the U.S. (Vitiello \& Brinkley 2014). Twenty years ago, planning scholars Pothukuchi and Kaufmann (2000) argued that "food is essential" (p. 117) and should be among other well recognized planning concerns such as housing, energy, environment, economy, and health. However, scholars have argued that local food and direct-to-consumer projects favor affluent communities and not the poor (Guthman, 2004; Guthman, Morris, \& Allen, 2006). Guthman et al. (2006) observed that direct-sale farmers tend to demand a higher price for their produce, so that in many locations across the U.S., community agriculture has been viewed as niche and non-essential. Nonetheless, research has shown that policy support for local food did not appear as a result of planning but rather emerged as a social and environmental movement in spite of planning (Thibert, 2012). Planners can support these local movements but must learn from the practitioners on the ground to support good food policy (Campbell, 2004; Thibert, 2012). Andrée, Clark, Levkoe, and Lowitt (2019) argue that communities' ability to prioritize local food systems has been highly dependent on grassroots-, county-, and state-level leadership. As such, the capacity of local food systems varies greatly across the U.S.

The declaration of the COVID-19 virus as a global pandemic by the World Health Organization on March 11, 2020 and as a national disaster in the U.S. two days later consequently brought about stay-at-home orders, travel restrictions, business closures, and recessions in many countries. Some of the first impacts on U.S. food producers were major declines in export markets and travel restrictions for seasonal laborers, resulting in substantial food waste (BBC News, 2020). As people sought to decrease their exposure at grocery stores, community supported agriculture (CSA) services, online sales, and home delivery services became popular and grew substantially (Lazaruk, 2020; Talty, 2020). As shut-downs continued, private and govern- 
mental aid began to flow, with billions of dollars coming from federal support via the Coronavirus Aid, Relief, and Economic Security (CARES) Act. But many barriers still remained: in April, Evich (2020) noted that "Tens of millions of pounds of American-grown produce is rotting in fields as food banks across the country scramble to meet a massive surge in demand, a two-pronged disaster that has deprived farmers of billions of dollars in revenue while millions of newly jobless Americans struggle to feed their families" (para. 1).

Food hubs are innovations in local food systems that help connect small farmers with local markets and increase food access for local residents (Matson, Sullins, \& Cook, 2013). In this paper, we examine roles and responses of food hubs-based on the experience of practitioners on the groundexploring challenges and opportunities that have emerged during the pandemic, and offer policy insights and suggest policy for future endeavors of food hubs and local food systems beyond the pandemic.

\section{Hawai'i's Food System, Food Hubs, and the Coronavirus}

Hawai'i's history suggests that the kanaka maoli (Native Hawaiians) were agriculturally selfsufficient for approximately a millennium by developing diverse agroecosystems (Lincoln \& Vitousek, 2017; Winter et al., 2020), supporting a population of 400,000 to 800,000 people prior to the arrival of Captain Cook in 1778 (Stannard, 1989). With colonization, Hawai'i replaced local food production with large-scale plantations for export and substantial food imports by joining global markets. By the early 1900s Hawai'i primarily relied on imported foods. Agriculture remained the largest economic driver until it was usurped by tourism following statehood in 1959 .

In the early 1970s the plantations began to close, with subleasing or subdividing of their substantial land holdings. The change in land tenure created more farms and farmers but significantly decreased the total land farmed, as areas were rezoned or left unattended (Page, Bony, \& Schewel, 2007). The natural result of smaller land parcels and more farmers was an increase in diversified agricultural production and forms (Lincoln \&
Ardoin, 2016b). Since the decline of plantation-era agriculture, public policy objectives have transitioned from promoting diversified agriculture which in Hawai i, as noted in the Office of Planning (2012b), was defines as "everything except sugar and pineapple" (p. 2) to promoting local food grown for local consumption and agricultural self-sufficiency (Office of Planning, 2012a, 2012b).

Movements such as "farm-to-fork" and Hawai'i Regional Cuisine further helped to link agriculture to Hawai'i's dominant economic engine: tourism. Unfortunately, Hawai'i still performs poorly in terms of food self-sufficiency, and now Hawaici imports approximately $85-90 \%$ of the food locally consumed (Loke \& Leung, 2013). The high number of small farms in Hawaici (over 6,500 of the 7,328 farms are less than 50 acres) range from subsistence, to hobby growers, to multipleincome farms, to bona fide farmers (Lincoln \& Ardoin, 2016a, 2016b). Local food sales grew from US $\$ 84.4$ million in 2015 (US $\$ 22.8$ million direct sales and US\$61.4 million wholesale) to US\$152.4 million in 2017 (US\$27.9 million direct sales and US\$124.5 million wholesale) (Pacific Region Farm News, 2016; USDA, 2017). In the U.S., sale of local food was $3 \%$ of all agricultural sales and involved $7.8 \%$ of farmers in 2017. By contrast, in Hawaici local sales make up $27 \%$ of all agricultural sales and involve 33\% of farmers in 2017 (USDA, 2017). However, this is still a small portion (about $4 \%$ ) of total food sales, which totaled US $\$ 3.7$ billion in 2005 (Leung \& Loke, 2008).

The oldest food hub in Hawai i, Adaptations, is 27 years old, but most of Hawai'i's food hubs are less than five years old. Prior to 2020, the food hub concept was relatively unknown in Hawai'i. In 2017, the Honolulu Star-Advertiser published an informational pamphlet on food hubs, "Food hubs help farms, boost access to local produce" (Oshiro, 2017). In 2017, the majority of Hawai i's food hubs (currently 11, and two in formation) joined a food hub group, the Food Hub Hui, facilitated by the Hawai'i Farmers Union United (HFUU) to discuss shared needs and explore ways to collectively increase support and recognition of Hawai'i's food hubs. The effort led to a legislative bill, the Food Hub Pilot Program (Hawaici State Legislature, 2020). The bill was accompanied by outreach 
efforts to the public in the form of op-eds and other written publications, and directly to legislators through infographics and testimony. Through these efforts, food hubs went from being relatively unknown to a commonly discussed solution for helping Hawai'i to reduce food imports (Viotti, 2020).

Hawai'i's first case of Coronavirus was officially announced on March 6, followed shortly by a mandatory 14-day quarantine for all travelers coming to Hawai $i$, the closure of public schools statewide, and stay-at-home orders for some counties (Young, 2020). Overnight, tourismwhich in 2019 generated US $\$ 2$ billion in state tax revenue and supported a third of all jobs in the state-declined nearly $99.9 \%$, causing one of the highest unemployment rates in the nation (O'Connor, 2020). Page et al. (2007) observed that Hawai'i farmers who participate in the local food industry cope with economic pressure by selling to high-end restaurant and hotels. The loss of tourism caused the immediate loss of a substantial component of the local agricultural markets. Coupled with public health directives that reduced patronage at restaurants and diminished spending due to high unemployment, local agriculture underwent a massive loss in demand.

\section{Community Food Security, Food Hubs and Food Systems Planning}

Local food systems or direct-to-consumer sales by farmers have emerged partly as an alternative to mainstream food and agricultural systems.

Research on the "food dollar" has shown that, nationally, most farmers received less than $10 \%$ of the money spent by the final consumers (Wilde, 2013). Food hubs provide an alternative to this value-chain model, with the vast majority of hubs stating that providing a fair price to producers is a central part of their mission (Colasanti et al., 2018). Community supported agriculture (CSA) and farmers markets are examples of direct agricultural markets, based on interactions of producers and consumers. These markets, according to Hinrichs (2000), "present an apparent counterpoint to large scale, more industrialized systems of food production and distribution, now under the growing control of a few seemingly unpeopled, yet powerful transnational corporations. If relations between producers and consumers are distant and anonymous in more 'global food system,' in local, direct markets, they are immediate, personal and enacted in shared space" (p. 295).

A food hub is an intermediary organization that manages the aggregation, distribution, and marketing of source-identified food products from local and regional farmers to strengthen their ability to satisfy wholesale, retail, and institutional demands (Barham et al., 2012). A food hub differs from other food distributors mainly in that most of its suppliers are exclusively growing local food and are therefore a component of a community or local food system. Although food hubs operate as an intermediary in direct-to-consumer systems, they often operate as a social enterprise and many are employee- or farmer-owned cooperatives. Thus food hubs have been described as "financially viable businesses that demonstrate a significant commitment to place through aggregation and marketing of regional food" (Fischer, Pirog, \& Hamm, 2015, p. 97). Furthermore, food hubs have been described as essential components of scalingup local food systems, and as flagship models of socially conscious business (Colasanti et al., 2018).

In Hawaici, food hub suppliers tend to be a mix of small and hobby farmers who have limited access to markets on their own as well as larger farms seeking to access different markets. This is similar to the national pattern, where nearly $90 \%$ of hubs report sourcing mostly or exclusively from small and medium sized farms (Colasanti et al., 2018). Food hubs support farmers by providing them with a reliable market, a challenge often expressed by small farmers (Day-Farnsworth \& Morales, 2016). By aggregating, food hubs are able to access larger and more diverse customer bases and contracts than the individual farmers, accessing the growing demand from larger buyers such as government institutions for local food.

\section{Community Participatory Research Approach and Methods}

This research gains some of its strong points from the authors' involvement in both research and practical application. Such hybrid roles of researchers being community activists has been 
highlighted in Indigenous Hawaiian research methods (Kahakalau, 2019). We utilize a participatory action research (PAR) methodology specifically adapted to Hawaiian communities, called Mā'awe Pono (Kahakalau, 2017). Mā'awe Pono, in a sense, is a deepening of the PAR method and includes a greater commitment to place-based knowledge about Hawaici and its people. Central concepts include local protocols, communication styles, and trust building. Mā'awe Pono also includes a strong heuristic element, similar to planning research methodology (Raja, Clark, Freedgood, \& Hodgson, 2018), in that it involves the researchers on a personal level, includes intuitive judgment and a spiritual dimension, and relies on common sense (Kahakalau, 2017).

In early 2017 , representatives of food hubs in Hawai' $i$ were convened with facilitation from the Hawai'i Farmers' Union United to discuss shared needs and explore collaborations. The group, which became the Food Hub Hui, initially consisted of five of the major food hub leaders in Hawai $i$ and grew to represent 11 food hubs in subsequent meetings. The principal author was the facilitator of the group in his official role as the HFUU Policy Committee Chair, and the second author was invited as an "ally" researcher within the local land-grant university. Initial meetings were informal "talk story" sessions in which participants got to know each other's stories and histories, as well as the current state of their businesses. Detailed procedural minutes and notes captured these conversations.

Shared visioning led to the group's initiative to draft and advocate for a bill in the 2020 Hawaici legislative session called The Food Hub Pilot Program (Hawai'i State Legislature, 2020). To strengthen their advocacy, the group agreed that documentation of their current impacts on economics and food systems would be useful. The authors facilitated an oral survey in September of 2019 to representatives from each of the 11 food hubs to gather quantitative data on their sales outlets, operations priorities measured by Likert scales, and Key Performance Indicators (KPI) such as annual revenues, number of employees, and farmers served.

Using data from the survey, the Food Hub Hui engaged in advocacy with Hawai'i State Legislators and a public awareness campaign to promote their impacts and bring awareness to the request for support. Although the bill was well received, the legislative session was never finished due to concerns over COVID-19. In response to the pandemic, the Agricultural Response and Recovery Working Group (ARRWG), an ad hoc communitybased advocacy group, was formed, seeking to (1) provide a unified voice to support local agriculture during the economic crisis, (2) highlight opportunities for CARES funds to support local agriculture, and (3) increase awareness of the vulnerabilities in Hawai'i's current food systems. As part of ARRWG's efforts, new data requests were made to multiple groups, including the Food Hub Hui. This led to a second round of data collection in September of 2020. Quantitative assessment of the KPI and sales outlets were again collected for the 11 food hubs to represent their "post-COVID" operations. During the second round, 30-45minute semi-structured interviews were conducted by the primary author with seven of the food hub leaders that explored their history, motivations, infrastructure, and COVID-19 response in depth. Interviews aimed to explore the unique nuances of each hub's step-by-step actions, priorities, and strategy to pivot. These interviews were recorded, transcribed, and coded into themes by the authors. We used a "directed content analysis" approach, which entailed first coding for relevant themes, then looking for themes emerging from the data (Hsieh \& Shannon, 2005). Coding involved the two authors (1) independently reading and rereading the transcripts, (2) independently coding the transcripts into themes, and (3) collectively comparing and discussing the independent codings to identify common themes. Recurring themes were considered more important. Interview questions focused on how the pandemic impacted their markets, major challenges that they faced, and how they overcame them. The two resulting data sets provide a look at the operations of the food hubs about six months before and six months after Hawai'i's closure to tourism. This study emerged not from a research directive, but from researchers working closely with community members and helping to solve problems and address their needs. 
The two researchers' position in respect to the various organizations demonstrates their involvement and engagement with the farming community of Hawaili (Figure 1).

\section{Results and Discussion}

We would like first to acknowledge the food hubs that have participated in this study, listed in Table 1. We have known their leaders to be passionate about local food systems, farmer well-being, and consumer health. As frequently said by the Adaptations manager, "nobody is in this industry for the money." To the best of our collective knowledge, this list represents the vast majority (over 95\%) of economic food hub activity in the state. They are evenly split between for- and nonprofit organizations, with one organization being a farmer-owned cooperative.

\section{Figure 1. Venn Diagram of the Two Authors and the Organizations Cited}

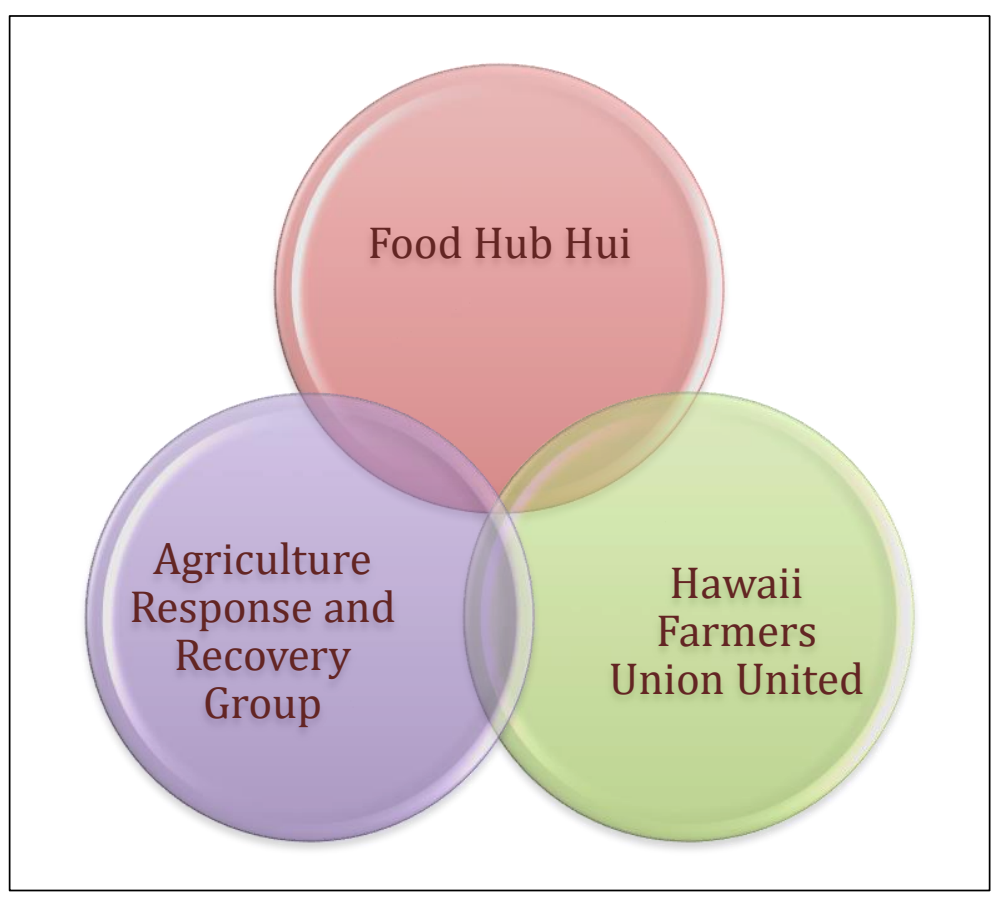

\section{Initial Shock and Increased Sales}

Prior to March 2020, food hubs supplied a fairly conventional customer base, with over $70 \%$ of sales going to restaurants, wholesale organizations, and institutional contracts. Several did have CSA programs or other direct sales, constituting approximately $28 \%$ of their combined sales. Hubs variably engaged in direct sales, with several not engaging at all, several having moderate levels (20$30 \%$ of sales), and a couple having direct sales as their primary outlet (approximately 90\%). At the onset of the global pandemic, several food hubs experienced a major loss of sales as restaurants stopped ordering and the Hawaii State Department of Education stopped purchasing food for school meals. One reported: "Pre-COVID, 95\% of our sales were comprised of food service including schools, hospitals, restaurants and hotels. In midMarch, when COVID hit, sales pretty much halted." Another said, "We primarily sold direct to restaurants. In one week, we almost lost all business. Before COVID, restaurants made up around $75 \%$ of sales." Several hubs acknowledged their vulnerability in conventional markets, one saying, "We were already concerned that we relied on a couple big buyers for the bulk of our sales. I've definitely thought before what would happen if they stopped buying." Leaders in these hubs "had been thinking of ways to diversify" revenue streams. Prior to the pandemic, other hubs had already transitioned or started transitioning their models away from wholesale. For example, Honolulu-based O'ahu Fresh said that they "had already been moving away from wholesale accounts, we had like maybe five wholesale accounts that we lost. It was only $10 \%$ of the business at the time."

With the dramatic and dynamic shifts in demand due to COVID, farmers and ranchers were in dire need of organizations able to aggregate and distribute local food. Many farmers who relied on direct relations with restaurants found themselves with surplus produce. At that time, many farmers turned to food hubs for the first time as a potential market. Virtually all hubs reported an increase in the number of farmers they sourced from, with a total increase from 664 to about 900 (Table 2). Simultaneously, the hubs also were developing new markets.

Increased demand for online CSA and "make- 
Journal of Agriculture, Food Systems, and Community Development

ISSN: 2152-0801 online

https:/ / foodsystemsjournal.org

Table 1. Food Hubs in Hawai'i that Participated in This Study

These represented the vast majority of the total volume and sales of all food hubs in the state.

\begin{tabular}{|c|c|c|c|}
\hline Food Hub & Location & Type & Products Offered \\
\hline Adaptations, Inc. & Captain Cook, Hawai‘i & LLC & $\begin{array}{l}\text { CSA service with home delivery, wholesale, SNAP } \\
\text { EBT }\end{array}$ \\
\hline Farm Link Hawai‘i & Haleiwa, Oahu & LLC & $\begin{array}{l}\text { CSA service with home delivery, wholesale, SNAP } \\
\text { EBT }\end{array}$ \\
\hline Hawai'i Ulu Cooperative & Kailua- Kona, Hawai‘i & Cooperative & Wholesale \\
\hline Kahumana Farm Hub & Wai‘anae, Oahu & Nonprofit & $\begin{array}{l}\text { CSA service with home delivery, wholesale, } \\
\text { farmers markets, community food distributions, } \\
\text { SNAP EBT }\end{array}$ \\
\hline Kohala Food Hub & Kohala, Hawai‘i & Nonprofit & CSA service \\
\hline Kokua Kalihi Valley & Kalihi, Oahu & Nonprofit & $\begin{array}{l}\text { Community food distributions, farmers market, } \\
\text { SNAP EBT }\end{array}$ \\
\hline Local Harvest & Lahaina, Maui & LLC & $\begin{array}{l}\text { CSA service with home delivery, wholesale, } \\
\text { community food donations }\end{array}$ \\
\hline Maui Food Hubs & Haiku, Maui & Nonprofit & $\begin{array}{l}\text { Online store, Community food distributions, SNAP } \\
\text { EBT }\end{array}$ \\
\hline Oahu Fresh & Honolulu, Oahu & LLC & \\
\hline Sustainable Molokai & Kaunakakai, Molokai & Nonprofit & $\begin{array}{l}\text { Mobile market, community food distributions, } \\
\text { SNAP EBT }\end{array}$ \\
\hline The Food Basket & Hilo, Hawai‘i & Nonprofit & $\begin{array}{l}\text { Mobile market, community food distributions, } \\
\text { SNAP EBT }\end{array}$ \\
\hline
\end{tabular}

your-own bag" products including home delivery constituted the first wave of sales increases. Starting in April, demand increased substantially, presumably as people sought to stay quarantined and avoid crowded grocery stores. The media picked up on the trend and further promoted CSAs, causing a further increase in demand. Several food hubs were listed publicly as an essential service, acknowledging the critical role they provided to health by reducing contact, particularly for the elderly. Food hubs provided Covid-19 specific services while many non-essential businesses closed their doors (e.g., Beers, 2020; Cheng, 2020; Gee, 2020; Honolulu Star-Advertiser, 2020; KHON2, 2020; Ruminski, 2020).

Responding to the surge in demand for direct sales was an essential first pivot for all the hubs. Adaptations hub said that "even though all the restaurants, with about six exceptions, shut down more than half of our income, our Fresh Feast CSA quadrupled over about four weeks, from 125 to 400 members, and that made up most of the loss." Some of the food hubs were already offering online CSA services and needed only to upgrade their practices to comply with COVID-19 guidelines. Sustainable Molokai said, "Our Mobile Market sales were already done online, so our main pivot was to change our neighborhood deliveries to drive-through model and of course implemented PPE and additional protocols to ensure food safety." Others had to quickly adapt and build new programs in order to access the market, one hub

Table 2. Key Performance Indicators (KPI) of the 11 Food Hubs Surveyed that Represent their Operations Prior to March 20202 and After June 2020

\begin{tabular}{lccc}
\hline & Before March 2020 & After June 2020 & Change (\%) \\
\hline Annual Revenue & US\$3,280,000 & US\$9,750,000 & 197\% \\
\hline No. of part-time jobs & 42 & 93 & $121 \%$ \\
\hline No. of full-time jobs & 25 & 53 & $112 \%$ \\
\hline No. of suppliers & 664 & 900 & $36 \%$ \\
\hline
\end{tabular}


saying, "We knew nothing about doing direct sales. We had no platforms to do it. We really had to start from scratch and put it together very quickly."

As the hubs expanded in direct sales, they also leveraged each other to offload excess production or to source produce for their clientele. This coordination also added a new category of sales between the hubs. For example, Kahumana Farm Hub (KFH) said, "O' $\mathrm{O}^{\prime}$ hu Fresh asked us to bundle green onions and Asian greens for their CSA. We already did it for our own CSA, so it was an easy service to add on." These hub-to-hub collaborations allowed hubs to cope with the quick growth of their respective CSA programs.

Several hubs had extended their CSA services to food-insecure people before the pandemic by accepting Supplemental Nutrition Assistance Program (SNAP) customers and, at times, offering them $50 \%$ discounts for affordability. Of the 11 surveyed, over $50 \%$ were already enrolled with SNAP and four were in the process of enrolling. In fact, over half stated that they had developed a food hub as a strategy to improve health and food access for in their own communities. This is consistent with national surveys that indicate that over $90 \%$ of hubs state that improving human health is a core, if not primary, value of their mission (Colasanti et al., 2018). Kokua Kalihi Valley (KKV), a food hub started in 2016, exemplifies these values:

We quickly determined the food hub provided access to highly nutritious produce for the community while overall food access was shrinking. The provisioning of food provided a related benefit strengthening connections to families and community members impacted by COVID or COVID restrictions. Eating healthy, adding immunity boosting foods to one's diet, and having regular contact with KKV health care providers with food distribution as the point of intersection have been a key to our community health system response. With this increased connection it has been easier to trace infections, share health information, model safe practices and answer questions from uncertain community members facing a pandemic.
The Adaptations hub took it one step further and created a "pay-it-forward" fund for vulnerable customers affected by lay-offs who could not afford their CSA. One of their members, a wealthy homeowner, contributed a US\$2,500 check to the fund. Adaptations stated, "It really did make a big difference for a number of people. There was one woman who was waiting for her SNAP approval and really was trying to decide between putting gas [in her car] and paying rent before she even used it up. So we gave her a US $\$ 500$ amount from the pay it forward fund. Before she ended using it all she was able to start paying with SNAP. So this is what it was supposed to do. It bridged her."

In April, a second wave of increased spending on local food came from distributions for relief feeding programs funded by philanthropic organizations as well as national, state, and county governments. In some cases, the use of local food in these feeding programs was mandated as a way to channel funds to local farmers and processors. This was particularly true with philanthropic donations that sought to maximize the impact of their dollars, which resulted in food distributors contacting the food hubs in order to appropriately source local products. In other cases, local food was encouraged but not required, as with most of the feeding programs that were funded by the CARES Act. In these cases, some hubs took a proactive approach, identifying the feeding programs and actively soliciting as a market opportunity. Local food sales also increased even when buying local was not a requirement, because normal supply lines were disrupted. For instance, the Food Basket was "unable" to procure rice for their family feeding program, and instead sourced locally grown and processed breadfruit as their primary carbohydrate.

Demand from community feeding programs was new to about half of the food hubs. One said, "We had about a month of horrible sales and then the community feeding programs started taking off and pretty much replaced our food service throughout until the end of June." Some of the hubs were contracted, or applied for funds, to do the distribution directly, leveraging their infrastructure and farmer relationships, while other hubs were subcontractors or major providers to external groups engaged in distribution programs. For 
example, KFH was subcontracted by the Waianae Comprehensive Health Center to provide "premade" CSA bags for community food distribution. In these cases, the contracting organization would give the food hub a budget per bag, which allowed the hub more flexibility in selecting items and more work opportunities for packaging and distributing the bags.

Hub-to-hub collaboration deepened as a result of the demand from community feeding programs. Hubs directly involved with food distributions sourced from hubs that were not. For example, the Food Basket was able to purchase breadfruit from the Hawaici Ulu Coop. Kokua Kalihi Valley sourced from KFH which, in some cases, was sourced from Adaptations Hawaici. As a result, increased food distributions for one hub meant increased sales for several other food hubs, although they were not the primary organization hired. In the survey, $91 \%$ of the food hubs agreed or strongly agreed that they connected more with other food hubs during the COVID-19 pandemic.

Total sales for the 11 food hubs went from US $\$ 3.2$ million prior to COVID-19 to US $\$ 9.7$ million after the pandemic, an increase of $197 \%$ (Figure 2). Some hubs increased as much as ten times in sales, hiring, and purchases, while one of the hubs decreased total sales but increased profitability because of earning higher margins with their shift to more direct-to-consumer sales. In the survey, $83 \%$ of the hubs agreed or strongly agreed that sales and the number of customers increased. In addition, $41 \%$ of the hubs reported that their profitability had improved because of more direct sales through CSA while $41 \%$ were neutral. Increased sales for the hubs also led to more employees (over $100 \%$ growth) and more purchasing of local food (Table 2). Current sales of US $\$ 9.7$ million is approximately equivalent to the value of $8 \%$ of all local food sales to retail markets, institutions, and food hubs for local or regionally branded products in Hawai'i (USDA, 2017).

\section{Figure 2. Shifts in Total Sales Outlets and the Standard Error Bars for Seven Food Hubs that Contributed Their Sales Data}

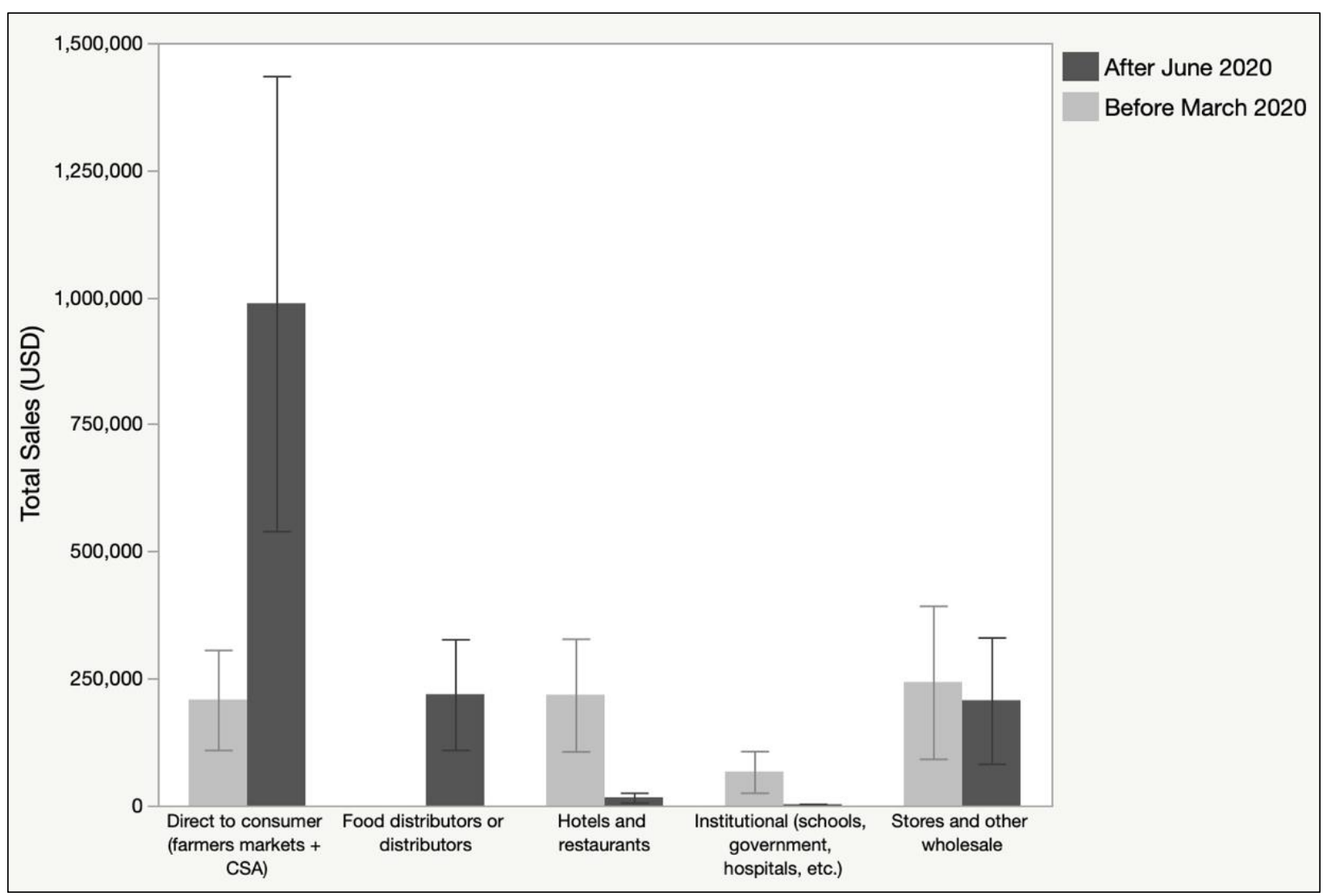


Another wave of CARES Act funding is expected, as Hawai'i has not spent its full federal allocation as of this writing. One hub commented, "I think I am going to be interested to see with the next few weeks [of September] through to December because I feel like the production has hit a rollercoaster all of a sudden. I see enormous amounts of CARES relief money that everyone is trying to spend very quickly because it has to be spent. And then the bottom is going to fall out in January, right?”

\section{Increased Purchases of Local Foods}

The increase in sales by the food hubs was coupled with increased supply. In the survey, $83 \%$ of hubs agreed or strongly agreed that they bought more food and $75 \%$ of them said they had many more suppliers coming on board. Hawai'i's food hubs currently work with about 900 farmers, which is about a third more farmers than before the pandemic (Table 2). This figure represents $12 \%$ of Hawai'i's farmers, and about a third of farmers who produce food for local consumption (USDA, 2017).

During this time, some hubs expanded their sourcing requirements. Previously, some hubs worked primarily with farmers using certified organic, organically managed, permaculture, backyard, and regenerative practices. As a result of COVID-19, these hubs began to include the full range of farmers, including those utilizing conventional practices. Almost all hubs said that they prefer to work with regenerative farmers, but at a minimum they all require their suppliers to provide full disclosure of their growing practices.

Several hubs pointed out that many new customers saw CSA and home delivery services as a replacement for trips to the store. In a short time, several food hubs pivoted from offering premade CSA bags to make-your-own bags to allow for greater consumer choice. The Kahumana Farm Hub manager explained, "Our customers started purchasing these build-your-own boxes in our online store. With that, we realized that they want those kinds of things because they say they don't want to go to the store. They want this to be their store. Also, our cafe started selling more ready-togo foods in both our farmers' markets and in our
CSA." Adaptations saw the same trend of people purchasing from their hub to prevent a trip to the store: "I think I have had a number of my friends say that they are now just relying on our store and then, like a once per month trip to Costco. By that, then they are not going to the farmer's market or even their local grocery store. They're trying to limit their contacts outside."

The shift in "specialty-to-staples" preferences for CSA customers is a new trend for many local producers and distributors that previously focused on luxury items. Several food hubs confirmed that new customers wanted to see a greater assortment of products. For example, O'ahu Fresh's founder said, "We are purchasing more food from the same farmers that we worked with before. But for the value-added products, we really added probably at least twenty new vendors." Public food distributions were catered to a different clientele than what most hubs had been used to, echoing the trend in CSA customers demanding more staples. As a result, several hubs started relying on more conventional foods and farmers. KFH shares their experience:

In our community, we have many Chinese, Laotian and Korean farmers who used to rely entirely on Chinatown in Honolulu. With the closure of businesses, these farms, many of them housed in Wai'anae, have been hugely affected. Because of the lower demands, they have had to drop prices on their onions, choy sum, bok choy, parsley, garlic chives and the many other vegetables they used to supply to Chinatown. The Kahumana Farm Hub has tried to support these farmers by distributing some of their vegetables through our popular Community Supported Agriculture home delivery program and in local food distributions.

$\mathrm{KFH}$, like many of the hubs, expressed their commitment to fair payment for farmers, such that seventy cents of every dollar spent on local food in their hubs goes to the producers. In some cases, the change in markets actually resulted in increased returns to farmers. For example, KFH increased their purchase price for many produce items: 
"because the CSA shift resulted in higher [profit] margin for us, we immediately started paying the growers more. That is a central part of our mission at Kahumana, to co-create healthy and inclusive communities."

The hubs that increased the most in sales were on $\mathrm{O}^{\prime} \mathrm{ahu}$, where most of the population of Hawai $\mathrm{i}$ resides. Many hubs relied on produce from outer islands where the bulk of agricultural production occurs. For example, KFH dramatically increased purchasing from Hawai'i Island during the pandemic (Figure. 3).

\section{More Workers, Warehouses, and Cars Supported by Partnerships and Government Grants}

In the survey, $83 \%$ of the food hubs reported they had to hire more workers, with the number of jobs growing by over $100 \%$ (Table 2). Full-time jobs provided by the hubs increased with the pandemic from 25 to 53, and part-time jobs from 42 to 93. O'ahu Fresh said, "We hired 12 more people. I just started reaching out to friends and my own social network. Combination of drivers, packers, admin, customer service, and web design." Every food hub hired more people in a short time span. Some were able to hire people who were laid off from other departments of their organization. Most of the food hubs established before the pandemic reported that they were able to benefit from the federal Payroll Protection Program.

The Food Basket provides a good illustration of the type of flexible worker that the food hubs hired: "A person that wants to work with us, is going to have to be really well-rounded, really flexible. The thing I have learned most about this is, you know, we have staff who are willing to jump in the trenches when we need extra hands at a community drop and that I can count on to have safe behavior given the pandemic. And at the same time, is not afraid to jump into a truck and drive or lend a hand with loading produce or packing produce." Rather than emphasizing specialized skills, the hubs looked for people who were flexible, good spirited, and community-driven. Several hubs were able to hire people who had been laid off from tourism industries, showing that the hubs could be sites for retraining and re-development. O'ahu Fresh said, "Pretty much everyone that came on had previously been working in restaurants and tourism. We had surf instructors and waiters. Everyone was working before but then had lost their jobs."

Several hubs also reported that they had to partner with other organizations to be able to expand their labor needs for storage, packing, and delivery. One hub reported, "Our business shifted to a lot more deliveries which we would not have been able to fulfill ourselves. We partnered with a

Figure 3. Purchases from Hawai'i Island by Kahumana Farm Hub, Situated on O‘ahu Island, September 2019 to June 2020

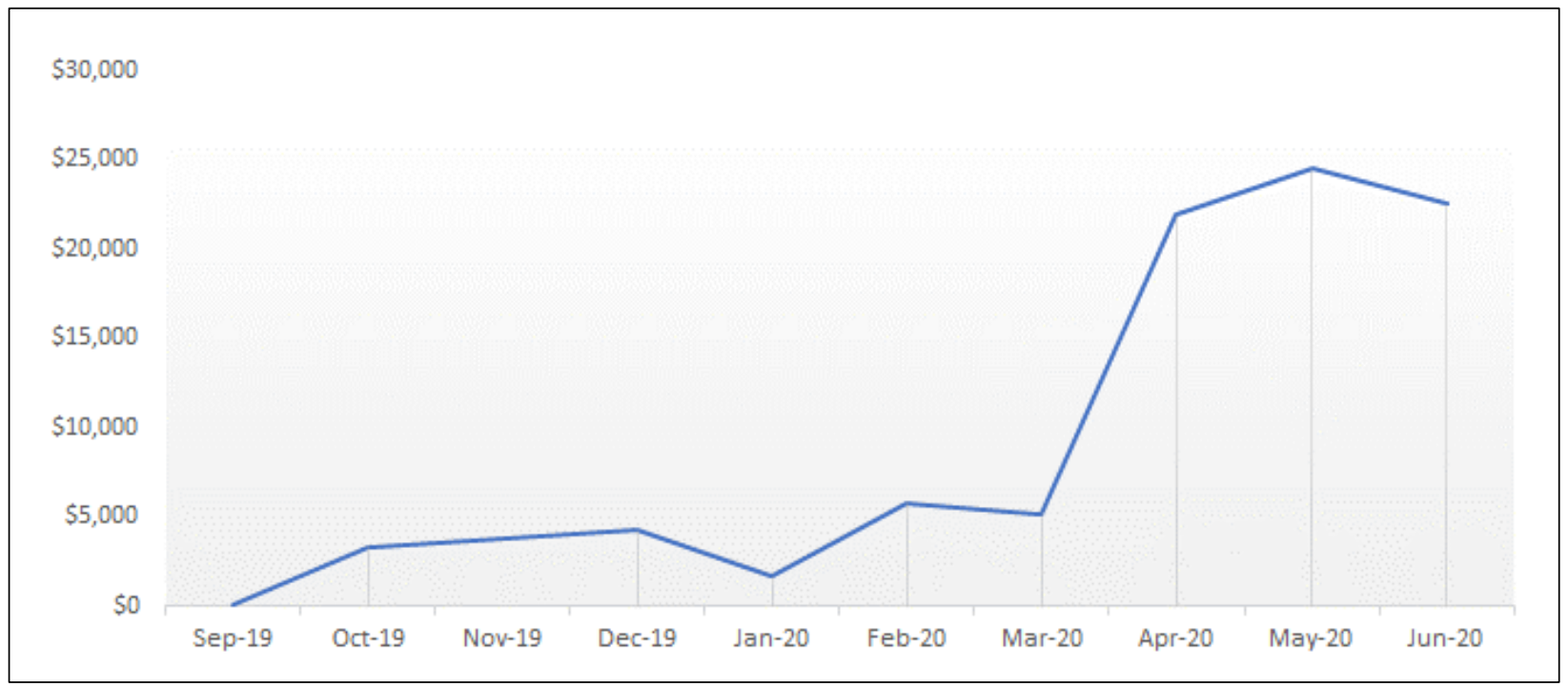


staffing company that began to provide support with home delivery by using their own vehicles." In March, the Maui Food Hub was launched as a response to the pandemic and partnered with an existing produce company to quickly build its CSA capacity. Maui Food Hub said, "We have been contracting with this facility Sun Fresh Hawaici, for our refrigerator space, vehicles, packing, and sorting labor. We reimburse Sun Fresh for about 6-8 workers a week." Furthermore, increased home deliveries had to be met with more refrigerated vehicles. A hub said, "Our whole transportation fleet became refrigerated. That happened because we were doing home deliveries. That way products would remain chilled all the way until it gets delivered. So it's only now that we're starting to consider frozen products." Hub-to-hub collaboration expanded from sourcing to include logistical needs, such as when KFH "hired O'ahu Fresh to bring multiple pallets per week from the harbor and airport to Wai'anae."

\section{Discussion and Closing Remarks}

\section{Local Food is Now More "Essential": Frontline Response of Food Hubs in Hawai i Mirror Experiences of Others}

In this paper we have examined the evolving role and response of food hubs in Hawaici to the COVID-19 pandemic. In the U.S., the CDC declared the provision of food and other essential goods an activity exempt from stay-at-home orders. The CDC also provided specific guidelines for farmers markets and CSA operations and encouraged the public to order food online or use curbside pickup whenever possible. Along with grocery stores, farmers markets and CSA operations became considered essential services overnight, by staying open with new and strict Covid19 rules. In contrast, many non-essential services temporarily closed or shut down permanently. Local food was not a necessity until the pandemic, which pushed small farmers and their networks, facilitated by food hubs, to be recognized as essential services. A co-owner of a San Francisco Hub, Veritable Vegetable (VV), illustrates the importance of food hubs and short supply-chains during the epidemic:
A chain is only as strong as its weakest link, and the longer a chain is, the more opportunities there are for stress and breakage. If you have a shorter chain, obviously you can repair and react quicker. (Curry, 2020, para. 12)

The example of Hawaici confirms the comment from VV that a short supply chain can respond more quickly to stress and breakage. Evidence suggests that the alternative food infrastructure led by Hawai'i food hubs quickly met the changing demand for food. The same COVID-19 trend of buying direct and local can be seen in multiple locations in the U.S. For example, Smith (2020) notes that in the COVID-19 era, many farms have created or expanded delivery services, bringing orders directly to homes. Small farmers who networked locally to expand or establish new informal co-ops, CSA operations, and food hubs have been successful during the pandemic because they responded to the public need for safe food. Held (2020) suggests from a New Mexico study that co-operatives selling CSAs online became a lifeline for farmers during the pandemic:

What emerged was the Better Together CSA, a cooperative effort that pooled their produce and resources to get fresh food to local families stuck at home. Now in its fourth membership cycle, the CSA has grown from 45 shares to 85 , with nine to 12 farms participating, depending on the week. (para. 4)

In Hawai i, hubs became a lifeline for farmers as illustrated by increased purchasing of local food by the hubs. All the hubs have supported small farmers and micro-entrepreneurs, but during the COVID-19 pandemic any Hawai'i farmer could benefit from the increased sales of the hubs and not just small and backyard farmers. The pandemic was also a period when more conventional farmers joined the food hub circles, which strengthened their ability to feed communities. The hubs facilitated strong inter-island networks that allowed for quick mobilization of produce from agriculturally rich regions such as Hawaíi and Maui Islands to feed people in $\mathrm{O}^{\prime}$ ahu, the most populated island. The networks are a testament to the 
work of the Hawai'i Farmers Union United, an organization that has fostered friendship and solidarity among small farmers and food hubs over the past 10 years.

Some actions of Hawai'i's food hubs also seem to be unique to Hawai'i. The hubs are communityoriented and have compassion for the poor and disadvantaged people in their communities, offering frontline responses for people who suffer from food insecurity. With the popularity of CSAs and home deliveries, Hawai'i hubs offered direct-toconsumer sales but did not forget about those in need by prioritizing SNAP EBT cardholders and providing discounts and services when possible. Almost $90 \%$ of the food hubs were involved in various ways with community food distribution programs. A few hubs purchased local food only for food distribution and not for CSAs or other direct markets.

Food insecurity rates in Hawai'i and the U.S. are far higher in rural areas (Feeding America, 2019). It has been projected that Hawai'i's food insecurity rate will increase by about $50 \%$ to some 233,000 people in 2020, from 151,000 in 2018, due to the effects of COVID-19 (Feeding America, 2020). In the seven and a half months after March 2020, 19 million pounds of food were distributed compared with 12 million for 2019 (Jung, 2020). Food hubs lower food insecurity in two ways: (1) by feeding vulnerable populations, and (2) by providing economic stimulus to food producers in rural areas. Improved profits by food hubs typically translate to higher payments to their growers. Many of the food hub suppliers are themselves suffering from food insecurity. A few hubs purchased local food only from community feeding programs and not for CSAs or other direct markets, further increasing sales for local growers struggling to keep their farms and provide for their own families. Food hubs provide stability for the local community and economy through purchases and sales.

\section{Sustaining Local Food Beyond the Pandemic?}

A question now is how can the increases in local food purchases be sustained after the pandemic? The pandemic has paved a path for local agriculture to transition from a luxury to a necessity.
While the hubs were quick responders to the pandemic, there is little evidence that demand for local food will persist. Even during the pandemic, small farmers received a fraction of the money designated for coronavirus relief while large, industrialized farms received the bulk of it (Ramgopal \& Lehren, 2020). The pandemic led to two strong currents of increased demand: (1) direct-toconsumer CSA online purchases and home deliveries, and (2) government purchasing of local food to distribute to vulnerable populations. From a food hub perspective, the first trend can grow with promotion and expansion to meet the demand. However, there is great uncertainty about continuation of government-supported public food distribution.

As demonstrated, food hubs can quickly respond to a food crisis. Hubs have built networks of farmers and markets that can adapt quickly to changing conditions on the ground. Investing in the physical and organizational infrastructure represented by food hubs should precede strategies for more production:

When we talk about doubling local food production, the emphasis is always on just thatproduction. For some reason there is a notion that if someone would just grow the food then everything else will fall into place. And so, the emphasis is always on the barriers to production-access to land, water, labor and capital. However, we ignore the fact that producing food is only the first step in a chain of activities needed to get that food to consumers. (Lincoln, 2020, para. 5-6)

Moving up the value-chain by addressing institutional hurdles to purchasing local food might be a better strategy than simply growing more food. The pandemic illustrates that state policies must be updated to strengthen local food systems. Five years before the pandemic, two farm-to-school pilot programs showed the potential to make a difference for local agriculture through institutional purchasing of local food (Hawaii State Department of Education, 2018). Currently, policymakers feel that it is urgent to establish more robust policies to build a strong local food economy that can with- 
stand shocks such as a global pandemic (Local Food Institutional Purchasing Hui, n.d.). Hawaiian public and private institutions are becoming more serious about supporting local agriculture through purchasing local produce as well as processed and cooked local foods for institutional food service. We argue that these types of policies have the potential not only to support farmers and food hubs but also to build resiliency against the next natural or manmade disaster.

\section{The Role of Local Food in Disaster Resilience}

During the pandemic and associated governmental restrictions, local food almost overnight went from a "luxury" item for affluent tourists to an essential service that had significant impacts on the wellbeing and the economics of the state. In particular, food hubs played an essential role in coordinating the flow of local produce from farmers to consumers. While the hubs were not necessarily equipped or prepared for a pandemic, they pivoted quickly. The roles and responses of food hubs and their networks through the pandemic demonstrate food systems resilience.

Resilience is typically thought of in terms of systems. Any significant shock, such as COVID19, has multiple, cascading effects within the system. In the case of COVID-19 there are social behavioral changes, economic impacts, supplychain issues, and so on. One reason for the substantial success of the food hubs is that they address multiple effects of the shock. Hubs source and hire local, and are dedicated to profit-sharing with farmers; funds injected into food hubs have a large multiplier effect on the local economy and employment (Schmit, Jablonski, \& Mansury, 2016). The economic multipliers of local food show that every $1 \%$ increase in consumption of locally produced food would result in US\$60 million in local sales and approximately 1,578 additional jobs (Leung \& Loke, 2008), and as more services are provided by food hubs, the multipliers are expected to increase. This is particularly attractive for CARES and other funding that seeks primarily to mitigate economic hardships.

In particular, we propose that institutional purchasing by government agencies such as the military and the Department of Education, and other government-funded purchasing, be required to buy local foods in order to maintain a minimum demand and supply of local production. This purchasing would necessitate minimum levels of local production, processing, and distribution to ensure that some base-level physical and organizational infrastructure is present in the local food system and available to respond during times of emergency. Leung and Loke (2008) calculated that for every US $\$ 100$ spent on local food in Hawai $i$, an additional US $\$ 2.25$ in tax revenue is generated (taking into account the lost revenues from reduced importation), offsetting some of the additional costs associated with locally produced food. Furthermore, these economic multipliers were calculated assuming a farm share of $25 \%$ of the food dollar, but, as demonstrated, food hubs often give a substantially higher share of revenue back to the farmer. Therefore, the cost of local food purchasing would be partially offset by increased economic multipliers and tax revenues while providing essential resilience infrastructure necessary for appropriate disaster response.

A core aspect of resilience is "functional redundancy": how many different players perform the same functions, so that if one fails during a shock, there are backups to continue to fulfill the role. For instance, due to panic purchasing in the U.S. there was a brief shortage of rice in Hawaici, and the Food Basket could not procure rice for its feeding programs. The Hawai'i Ulu Producers Cooperative was able to replace rice with breadfruit until the supply lines recuperated. The redundancy of the production of staple carbohydrates locally even when $99 \%$ of carbohydrates are imported can play critical roles when the primary functions fail. Hub-to-hub collaborations exemplify the functional redundancy that contributes to community resilience.

If local food does enhance the resilience of a food system, it implies benefits to disaster planning that go beyond simple economics. Compassionate practitioners rather than proactive planners have built Hawai'i's local food movement. Local food planning has not been prioritized in government policies and programs, despite well-stated priorities of food security (Economic Development Alliance of Hawai'i, 2016; Ige, 2017). While imported food 
supplies were temporarily disrupted by the pandemic, a more significant disaster or a combination of disasters could have more drastically affected imports, making local food a greater necessity. Nobody anticipated that the hubs were going to position themselves as responders to the pandemic. Governmental policies must value resilience as an essential strategy and the role of food hubs in functional redundancy and a strong local food economy. While hubs have been described as a key component of scaling-up local food systems and a flagship model of socially conscious business, their response to the COVID-19 pandemic in Hawaii and in the U.S. suggests that they fill a vital function through their provision of essential services during disaster.

\section{References}

Andrée, P., Clark J. K., Levkoe, C. Z., \& Lowitt, K. (Eds.). (2019). Civil society and social movements in food system governance. Abingdon, UK \& New York: Routledge.

Barham, J., Tropp, D., Enterline, K., Farbman, J., Fisk, J., \& Kiraly, S. (2012). Regional food bub resource guide (Research report 145227). Washington, DC: U.S. Department of Agriculture, Agricultural Marketing Service, Transportation and Marketing Program. https://doi.org/10.22004/ag.econ.145227

BBC News. (2020, April 13). Coronavirus: Five ways the outbreak is hitting global food industry. BBC News. https://www.bbc.com/news/world-52267943

Beers, A. (2020, April 22). Maui food hub launches to connect people and farms. Wailuku, HI: ManiTime. https://mauitime.com/news/business/maui-food-hub-launches-to-connect-people-and-farms

Béné, C. (2020). Resilience of local food systems and links to food security-A review of some important concepts in the context of COVID-19 and other shocks. Food Security, 12, 805-822. https://doi.org/10.1007/s12571-020-01076-1

Cheng, M. (2020, March 24). Support Hawai'i's farmers and get produce delivered to your door. Honolulu Magazine. https://www.honolulumagazine.com/support-hawaiis-farmers-and-get-produce-delivered-to-your-door/

Colasanti, K., Hardy, J., Farbman, J., Pirog, R., Fisk, J., \& Hamm, M. W. (2018). Findings of the 2017 National Food Hub Survey. East Lansing: Michigan State University, Center for Regional Food Systems, The Wallace Center at Winrock International. https://www.canr.msu.edu/foodsystems/uploads/resources/2017\%20national $\% 20$ food $\% 20$ hub $\% 20$ survey $\% 20$ fin dings.pdf

Curry, L. (2020, July 30). The nation's oldest organic produce distributor is weathering the pandemic. Civil Eats. https://civileats.com/2020/07/30/the-nations-oldest-organic-produce-distributor-is-doing-just-fine-in-thepandemic/

Day-Farnsworth, L., \& Morales, A. (2011). Satiating the demand: Planning for alternative models of regional food distribution. Journal of Agriculture, Food Systems, and Community Development, 2(1), 227-247. https://doi.org/10.5304/jafscd.2011.021.020

Economic Development Alliance of Hawai'i (EDAH). (2016). Hawaii statewide comprehensive economic development strategy. Honolulu, HI: EDAH. http://files.hawaii.gov/dbedt/op/spb/CEDS 2016 final.pdf

Ericksen, P. J. (2008). What is the vulnerability of a food system to global environmental change? Ecology and Society, 13(2), Art. 14. https://doi.org/10.5751/ES-02475-130214

Evich, H. B. (2020, April 26). USDA let millions of pounds of food rot while food-bank demand soared. Politico. https://www.politico.com/news/2020/04/26/food-banks-coronavirus-agriculture-usda-207215

Feeding America. (2019). Map the meal gap 2019. Chicago: Feeding America. https://map.feedingamerica.org/

Feeding America (2020). The impact of the coronavirus on food insecurity in 2020. Chicago: Feeding America. https://www.feedingamerica.org/sites/default/files/2020-10/Brief Local\%20Impact 10.2020 0.pdf

Fischer, M., Pirog, R., \& Hamm, M. W. (2015). Food hubs: Definitions, expectations, and realities. Journal of Hunger \& Environmental Nutrition, 10(1), 92-99. https://doi.org/10.1080/19320248.2015.1004215

Foley, J. A., Ramankutty, N., Brauman, K. A., Cassidy, E. S., Gerber, J. S., Johnston, M., ... Zaks, D. P. M. (2011). Solutions for a cultivated planet. Nature, 478, 337-342. https://doi.org/10.1038/nature10452 
Gee, P. (2020, April 6). O‘ahu Fresh subscription services link farms, homes. Honolulu Star-Advertiser. https://www.staradvertiser.com/2020/04/06/hawaii-news/oahu-fresh-subscription-services-link-farms-homes/

Godfray, H. C. J., Crute, I. R., Haddad, L., Lawrence, D., Muir, J. F., Nisbett, N., ... Whiteley, R. (2010). The future of the global food system. Philosophical Transactions of the Royal Society B, 365(1554). https://doi.org/10.1098/rstb.2010.0180

Guthman, J. (2004). The trouble with 'organic lite' in California: A rejoinder to the 'conventionalisation' debate. Sociologia Ruralis, 44(3), 301-316. https://doi.org/10.1111/j.1467-9523.2004.00277.x

Guthman, J., Morris, A. W., \& Allen, P. (2006). Squaring farm security and food security in two types of alternative food institutions. Rural Sociology, 71(4), 662-684. https://doi.org/10.1526/003601106781262034

Hawaii State Department of Education (HIDOE). (2021) 'Āina pono programs. https://www.hawaiipublicschools.org/ConnectWithUs/Organization/Offices/FacilitiesandOperations/SchoolFoo dServices/f2s/Pages/default.aspx\#

Hawai'i State Legislature. (2020). S. B. 2722 S. D. 1. A bill for an act relating to a food hub pilot program. Honolulu, HI: Hawai'i State Capitol. https://www.capitol.hawaii.gov/session2020/bills/SB2722 SD1 .HTM

Held, L. (2020, September 14). For small farms surviving the pandemic, co-ops are a lifeline. Civil Eats. https:// civileats.com/2020/09/14/for-small-farms-surviving-the-pandemic-co-ops-are-a-lifeline

Hinrichs, C. C. (2000). Embeddedness and local food systems: Notes on two types of direct agricultural market. Journal of Rural Studies, 16(3), 295-303. https://doi.org/10.1016/S0743-0167(99)00063-7

Honolulu Star-Advertiser. (2020, May 5). Farm to you: Connecting consumers with Hawaii farmers, ranchers and fishers. Star Advertiser. Retrieved from https://www.staradvertiser.com/2020/05/05/food/farm-to-you-a-resource-guideto-help-connect-consumers-with-Hawaii-farmers/

Hsieh, H.-F., \& Shannon, S. E. (2005). Three approaches to qualitative content analysis. Qualitative Health Research, 15(9), 1277-1288. http://dx.doi.org/10.1177/1049732305276687

Ige, D. (2017). Governor David Ige’s priorities for Hawai $i$. Honolulu, HI: Hawai'i State Government. https://governor.hawaii.gov/governor-david-iges-priorities-for-hawai $\% \mathrm{CA} \% \mathrm{BBi} /$

Jones, M. (2013). What does resilience mean to food security and poverty alleviation? (SIANI policy brief). Stockholm: Swedish International Agricultural Network Initiative. https://www.siani.se/news-story/siani-policy-brief-what-doesresilience-mean-food-security-and-poverty-alleviation/

Jung, Y. (2020, Nov. 24). COVID-19 is changing 'the face of hunger' in Hawaii. Honolulu Civil Beat. https://www.civilbeat.org/2020/11/covid-19-is-changing-the-face-of-hunger-in-hawaii/

Kahakalau, K. (2017). Developing an Indigenous proficiency scale. Cogent Education, 4(1), 1377508. https://doi.org/10.1080/2331186X.2017.1377508

Kahakalau, K. (2019). Utilizing Mā'awe Pono as a framework and methodology for research in the area of systems change benefiting the Native Hawaiian Lāhui. In C. Mello, L. Riley, \& C. Graham-Tutt (Eds.), 'Imi Na'auao: Hawaiian knowing and wellbeing: Research to affirm the qualities of Hawaiian health and wellness (pp. 23-32). Kapolei, HI: University of Hawaici.

KHON-2. (2020, March 27). Kabumana Organic Farms delivers fresh produce, meals during social distancing. Honolulu, HI: KHON-2. https://www.khon2.com/coronavirus/kahumana-organic-farms-delivers-fresh-produce-meals-duringsocial-distancing/

Lazaruk, S. (2020, September 26). Vancouver Farmers Market offers online ordering and delivery for local produce. Vancouver Sun. https://vancouversun.com/health/vancouver-farmers-market-offers-online-ordering-and-deliveryfor-local-produce

Leung, P., \& Loke, M. K. (2008). Economic impacts of increasing Hawai i's food self-sufficiency (Economic Issues 16). Honolulu: University of Hawaici, College of Tropical Agriculture and Human Resources, Cooperative Extension Services.

Lincoln, N. K., (2020, February 12). Here's an even better vision for food sustainability: What are the real barriers to increasing local food production, self-sufficiency and agricultural vitality? Honolulu Civil Beat. https://www.civilbeat.org/2020/02/heres-an-even-better-vision-for-food-sustainability/ 
Lincoln, N. K., \& Ardoin, N. (2016a). Cultivating values: Environmental values and sense of place as correlates of sustainable agricultural practices. Agriculture and Human V alues, 33(2), 389-401. https://doi.org/10.1007/s10460-015-9613-Z

Lincoln, N. K., \& Ardoin, N. (2016b). Farmer typology in South Kona, Hawai'i: Who’s farming, how, and why? Food, Culture \& Society, 19(3), 563-585. https://doi.org/10.1080/15528014.2016.1208341

Lincoln, N. K., \& Vitousek, P. (2017). Indigenous Polynesian Agriculture in Hawai'i. In Oxford Research Encyclopedia of Environmental Science. Oxford, UK: Oxford University Press. https://doi.org/10.1093/acrefore/9780199389414.013.376

Local Food Institutional Purchasing Hui. (n.d.). Local Food Institutional Purchasing Hui. Retrieved February 2021 from https://sites.google.com/view/localfoodiph/meetings?authuser $=0$

Loke, M. K., \& Leung, P. (2013). Hawai'i's food consumption and supply sources: Benchmark estimates and measurement issues. Agricultural and Food Economics, 1, Art. 10. https://doi.org/10.1186/2193-7532-1-10

Matson, J., Sullins, M., \& Cook, C. (2013). The role of food hubs in local food marketing (Rural Development Service Report 73). Washington, DC: U.S. Department of Agriculture. https://www.rd.usda.gov/files/sr73.pdf

O’Connor, C. (2020, June 29). Hawai'i visitor arrivals drop by nearly $100 \%$ for second consecutive month. Pacific Business News. https://www.bizjournals.com/pacific/news/2020/06/29/visitor-arrivals-continue-to-decline.html" https://www.bizjournals.com/pacific/news/2020/06/29/visitor-arrivals-continue-to-decline.html

Office of Planning. (2012a). Increased food security and food self-sufficiency strategy. Honolulu, HI: Office of Planning, Department of Business Economic Development \& Tourism. https://files.hawaii.gov/dbedt/op/spb/INCREASED FOOD SECURITY AND FOOD SELF SUFFICIEN CY STRATEGY.pdf

Office of Planning. (2012b). Increased food security and food self-sufficiency strategy. Volume II: A history of agriculture in Hawaii and technical reference document. Honolulu, HI: Office of Planning, Department of Business Economic Development \& Tourism.

http://files.hawaii.gov/dbedt/op/spb/Volume II History of Agriculture in Hawaii and Technical Reference Document FINAL.pdf

Oshiro, J. (2017, September 5). Food hubs help farms, boost access to local produce. Honolulu Star-Advertiser. https://www.staradvertiser.com/2017/09/05/food/food-hubs-help-farms-boost-access-to-local-produce/

Pacific Region Farm News. (2016, Dec. 21). Local food sales reaches \$84.4 million in Hawaii. Honolulu, HI: USDA, National Agricultural Statistics Service. https://hdoa.hawaii.gov/wp-content/uploads/2016/12/122016LocalfoodHI.pdf

Page, C., Bony, L., \& Schewel, L. (2007). Island of Hawaii whole system project: Phase I report. Boulder, CO: Rocky Mountain Institute. http://www.kohalacenter.org/pdf/hi wsp 2.pdf

Pingali, P., Alinovi, L., \& Sutton, J. (2005). Food security in complex emergencies: Enhancing food system resilience. Disasters, 29(S1), S5-S24. https://doi.org/10.1111/j.0361-3666.2005.00282.x

Pothukuchi, K., \& Kaufman, J. (1999). Placing the food system on the urban agenda: The role of municipal institutions in food systems planning. Agriculture and Human Values, 16(2), 213-224. https://doi.org/10.1023/A:1007558805953

Pothukuchi, K., \& Kaufman, J. (2000). The food system: A stranger to the planning field. Journal of the American Planning Association, 66(2), 113-124. https://doi.org/10.1080/01944360008976093

Ramgopal, K., \& Lehren, A. W. (2020, August 9). Small farmers left behind in Trump administration's COVID-19 relief package. NBC News. https://www.nbcnews.com/business/economy/small-farmers-left-behind-trumpadministration-s-covid-19-relief-n1236158

Raja, S., Clark, J. K., Freedgood, J., \& Hodgson, K. (2018). Reflexive and inclusive: Reimagining local government engagement in food systems. Journal of Agriculture, Food Systems, and Community Development, 8(Suppl. 2), 1-10. https://doi.org/10.5304/jafscd.2018.08B.013

Rockström, J., Steffen, W., Noone, K., Persson, A., Chapin III, F. S., Lambin, E., ... Foley, J. (2009). Planetary boundaries: Exploring the safe operating space for humanity. Ecology and Society, 14(2), Art. 32. https://doi.org/10.5751/ES-03180-140232 
Ruminski, L. (2020, April 9). Keeping the supply chain running: Farmers need support to weather virus. West Hawaii Today. https://www.westhawaiitoday.com/2020/04/09/hawaii-news/keeping-the-supply-chain-running-farmersneed-support-to-weather-virus/

Schmit, T. M., Jablonski, B. B. R., \& Mansury, Y. (2016). Assessing the economic impacts of local food system producers by scale: A case study from New York. Economic Development Quarterly, 30(4), 316-328. https://doi.org/10.1177/0891242416657156

Smith, C. B. (2020, July 31). A look at the serious growth in our local food system. Cincinnati Magazine. https:/ /www.cincinnatimagazine.com/local-food-2020/a-look-at-the-serious-growth-in-our-local-food-system/

Stannard, D. E. (1989). Before the horror: The population of Hawaiti on the eve of Western contact. Honolulu, HI: University of Hawaici Press.

Talty, A., (2020, July 30). Volunteers save New York's oldest community farm as COVID-19 hits agriculture. The Guardian [U.S. ed.]. https://www.theguardian.com/environment/2020/jul/30/csa-farms-covid-19-agriculture

Tendall, D. M., Joerin, J., Kopainsky, B., Edwards, P., Shreck, A., Le, Q. B., ... Six, J. (2015). Food system resilience: Defining the concept. Global Food Security, 6, 17-23. https://doi.org/10.1016/i.gfs.2015.08.001

Thibert, J. (2012). Making local planning work for urban agriculture in the North American context: A view from the ground. Journal of Planning Education and Research, 32(3), 349-357. https://doi.org/10.1177/0739456X11431692

Ungar, M. (2018). Systemic resilience: Principle and processes for a science of change in contexts of adversity. Ecology and Society, 23(4), Art. 34. https://doi.org/10.5751/ES-10385-230434

U.S. Department of Agriculture. (2017). Census of Agriculture. Washington, DC: USDA, National Agricultural Statistics Service. https://www.agcensus.usda.gov/Publications/2012/Full Report/Volume 1, Chapter 1 State Level/Hawaii/hiv1 .pdf

Viotti, V. (2020). Q\&A with Phyllis Shimabukuro-Geiser, head of Hawaii Board of Agriculture. Honolulu Star-Advertiser. https://www.staradvertiser.com/2020/06/26/editorial/5-questions-with/phyllis-shimabukuro-geiser-the-head-ofthe-hawaii-board-of-agriculture-hopes-to-build-on-the-current-demand-for-locally-grown-food/

Vitiello, D., \& Brinkley, C. (2014). The hidden history of food system planning. Journal of Planning History, 13(2), 91-112. https://doi.org/10.1177/1538513213507541

Wilde, P. (2013). Food policy in the United States: An introduction. London, UK: Routledge. https://doi.org/10.4324/9780203121795

Winter, K. B., Lincoln, N. K., Berkes, F., Alegado, R. A., Kurashima, N., Frank, K. L., ... Toonen, R. J. (2020). Ecomimicry in Indigenous resource management: Optimizing ecosystem services to achieve resource abundance, with examples from Hawai'i. Ecology and Society, 25(2), Art. 26. https://doi.org/10.5751/ES-11539-250226

Young, C. (2020, August 3). A COVID-19 timeline: How Honolulu got to this point. Honolulu Magarine. http://www.honolulumagazine.com/Honolulu-Magazine/August-2020/A-COVID-19-Timeline-How-HonoluluGot-To-This-Point/ 